\title{
A Methodological Outlook on Bioplastics from Renewable Resources
}

\author{
Jomin Thomas \\ Department of Polymer Engineering, University of Akron, Akron, Ohio, USA \\ Email:jominjts@gmail.com
}

How to cite this paper: Thomas, J. (2020) A Methodological Outlook on Bioplastics from Renewable Resources. Open Journal of Polymer Chemistry, 10, 21-47. https://doi.org/10.4236/ojpchem.2020.102002

Received: May 9, 2020

Accepted: May 27, 2020

Published: May 30, 2020

Copyright $\odot 2020$ by author(s) and Scientific Research Publishing Inc. This work is licensed under the Creative Commons Attribution International License (CC BY 4.0).

http://creativecommons.org/licenses/by/4.0/

\begin{abstract}
Bio plastics products have a rapid growing demand and market across the globe. Polymers synthesized from renewable resources have gained immense popularity, in numerous applications ranging from films, bottles, food packaging, drug delivery, bags to agriculture mulch films. Various naturally occurring resources available for starch and PLA extraction and the associated polymer processing techniques are discussed. Alongside some basic concepts on blown film extrusion, the modifications needed for such specialized polymer processing techniques are also explored, giving a comprehensive outlook on bioplastics. Special process analysis, for its application as films are discussed. In the current scenario, as the world aspires for environmental and polymer sustainability, Bioplastic products are of high value. The review article would be beneficial to those embarked on designing bio-plastics products from renewable resources.
\end{abstract}

\section{Keywords}

Thermoplastic Starch, Polylactic Acid PLA, Extrusion, Blown Film Extrusion, Gelatinization, Plasticization, Bioplastics, Polymer Sustainability

\section{Introduction}

One of the greatest inventions in the twentieth century can be undoubtedly stated as plastics. The advantage of plastics being light weight also paves the way for its widespread pollution occupying a large area in landfills. Further, plastic add to the litter problem for land and sea alike. With the expansion of advertising propagandas, companies have started to perpetualize a concept of sustainability in almost all their products and establish their products as "green products". It ranges from the big players in the cloth industry to various companies in paint industry and construction materials who claims to have complete bio- 
renewable resources in their base formulations. Sustainability is stated as "meeting the needs of the current generation without compromising the ability of future generations to meet their needs" by the 1987 United Nations Conference [1]. The concept of green chemistry and green engineering also has come up in the horizon of polymer sustainability. Green chemistry gives importance to the elimination of use of toxic and hazardous materials [2] whereas green engineering aligns itself to design better environmentally friendly products and alternatives for conventional products [3]. Life Cycle assessment (LCA) is also one of the key and essential analyses to study the environment impact and greenhouse gas emissions of the process, products, and systems. Advantages of LCA include a thorough and worldwide established approach to eventually analyze the outcome of environmental impacts of processes and products in terms of measurable outcomes [4].

Bio based, biodegradable and recycled plastics are referred to as the sustainable plastics. Among its sustainable prospective, using bioplastics made from renewable resources and incorporating a sustainable manufacturing processes with lower carbon footprint and energy are just few of the many initiatives. Bioplastics are now widely used, and the best example would be the new Dasani "plant bottle" commonly seen in USA which is made up of $30 \%$ plant material with Polyethylene Terephthalate (PET) being the other component. 100\% corn starchbased bottles are also in the market, like the Pimo water bottles [5]. Few of the points against bioplastics can be the use of toxic pesticides sprayed on crops. Use up of fossil fuels, if not in making bioplastic, are still inevitable for powering plants and further, there is carbon dioxide emissions from harvesting vehicles. Amidst a strong tide of plastic pollution and the far cry for banning plastic products, Bioplastics have the potential to be a revolution in plastic industry. It has the potential to reiterate the plastic industry into more environmentally sustainable industry though it has few points constraining its commercial usage. These constraints need to surpass for bioplastics to be used as a viable replacement of many conventional plastics. A thorough understanding of the bioplastics is thus highly valuable and is the need of the hour.

Bioplastics are broadly classified into two main categories [6]. They are divided into biodegradable (compostable) plastics and bio-based plastics. The division is primarily based on the source and life cycle perspectives. Plastics derived from renewable resources which are either bio-degradable or non-biodegradable, come under the scope of bio-based plastics. Plastics that fulfills the requirement of biodegradability and compossibility are referred to as the biodegradable plastics. Three main classes of biodegradable materials are widely recognized. First among them is the synthetic polymers from the nonrenewable resources which are highly susceptible to the hydrolysis attack. Second is the naturally occurring bacterial polymers like the Polyhydroxybutyrates and Polyhydroxyvalerates. The third class is the one of the primal focus of this paper, biodegradable polymers, or bioplastics from renewable resources. They include cellulose, starch and polylactic acid which are among the most investigated [7]. However, a plethora of certifi- 
cation and standard norms need to be followed before it is categorized into the bio-plastic strata [8]. In the 2009 guidelines for sustainable plastics, Sustainable Biomaterials collaborative based in Washington DC defined bioplastics as, sourced from sustainably grown such that there is no hazardous or toxic inputs and impact elements. Additionally, it should also be environmentally safe to use and should possess the scope of reutilizing at the end of their life cycle [9]. Starch \& Polylactic acid (PLA) is undoubtedly two of the most extensively studied biopolymers, even to a full life cycle assessment study. Various research work has been carried out regarding the lesser radiation to environment by the reduced carbon emissions [10] and the lower energy needed to produce such biopolymer pellets [11]. Demands of such a category have its root to the recent changes and the wave of sustainability in the society.

\section{Renewable Resources for Bioplastics}

Any polymer made from natural ingredients (starch, corn, tapioca, rice, sugarcane), oils (soya, palm or linseed) and fermentation products (Polyhydroxybutyrates (PHB), polylactic acid (PLA) and polyhydroxyalkanoate (PHA)), come under the category of bio-based polymers [12]. Most common among them are the PLA, PHA and TPS (Thermoplastic Starch). They are used in packaging industry, for containers, bottles, films, sheets, trash bags and agricultural munches. Before, we discuss on the bio sourced plastics, let us look at the conventional side in a jest. Conventional plastics are also produced from organic resources like bio-based PE and bio-based PET resins [13]. From sugarcane and other agricultural products, bioethanol is produced which acts a s a precursor to both bio-PP and bio-PE production [14]. Bio based PET is manufactured from Methylene ethylene glycol (MEG) and terephthalic acid from sugar, starches and cellulose based materials using isobutanol and para xylene intermediates and selective $\mathrm{Co} / \mathrm{Mn}$ catalysts [15]. sugarcane waste or bagasse contains majorly cellulose which has glucose in crystalline structure [16]. They are used as paper products through modified paper pulping process [17]. Bagasse based food service products can thus serve as a replacement to the Styrofoam products. Further, with PLA/PHA coating, enhancement of water barrier properties is also possible [18]. Among the petroleum-based biodegradable polymers, the most common are the Eco flex ${ }^{\oplus}$, ecovio ${ }^{\oplus}$, and PCL can be processed into plastic bags [19]. Polycaprolactone PCL produced from ring-opening polymerization of $\varepsilon$-caprolactone and Poly (butylene succinate) which is a poly condensation reaction of butanediol and succinic acid using catalysts, are additives blended with TPS or PLA to produce plastic bags and containers. PBS can also be injection molded into products at an injection pressure of 90 bar, barrel temperatures between $140^{\circ} \mathrm{C}$ and $160^{\circ} \mathrm{C}$, and mold temperature of $20^{\circ} \mathrm{C}$ [20].

\subsection{PHA}

PHA based polymers can be made from innumerous monomers which are de- 
rivatives of poly(4-hydroxybutyrate) (PHV) and poly(3-hydroxyalkanoates) (PHB) and are later harvested from the cells of bacteria [21] It is attributed to the hydroxy repeat units formed by the fermentation of bacterial with sugar, forming linear polyesters [22]. PHA has similar properties as Polypropylene (PP) and can be injection molded to products like bottles, containers etc. at a temperature range between $160^{\circ} \mathrm{C}$ to $190^{\circ} \mathrm{C}$. Below $160^{\circ} \mathrm{C}$ the viscosity is too high and above $190^{\circ} \mathrm{C}$, PHA tend to thermally decompose [23]. Mirel P is one example of PHA product industrially manufactured [24]. Extrusion of PHA polymers are also possible (Tianan PHA products) but are added with additives and nucleating agents in twin screw extruders with 40:1 Length to diameter ratio while compounding. These concepts will be discussed in detail in the successive sections [25]. Switch grass can also be genetically modified to produce PHA and used for bioplastic manufacturing.

\subsection{PLA}

PLA is the most important biopolymer in the market. Chemically, Polylactic acid is an aliphatic polyester which can be derived from natural resources like starch and sugar. PLA has the largest amount of biopolymer processed across the globe and thoroughly studied by polymer scientists. To manufacture PLA, the first step is the harvesting and isolation of corn followed by conversion of starch into dextrose. This glucose is later fermented to lactic acid with the aid of bacteria and are polymerized into PLA pellets [26]. However, there is also a possibility of producing PLA using spent grains and organic wastes as reported by various authors [27]. Chemical synthesis routes are also possible. They include lactonitrile hydrolysis by strong acids, propylene glycol oxidation, acetaldehyde based chemical reactions [28]. High molecular weight PLA are manufactured by either lactide ring opening polymerization, direct or azeotropic dehydrative condensation polymerization [29]. They are copolymers of PLLA (poly (L-lactic acid)) and PDLLA (poly(l-lactic acid) [30]. Even though $\mathrm{Tg}$ and $\mathrm{Tm}$ depends on molecular weight and polymer optical purity, it ranges to $60^{\circ} \mathrm{C}$ and $150^{\circ} \mathrm{C}$ respectively. The high molecular weight melts of PLA follow a pseudoplastic, non-Newtonian behavior whereas low molecular weight PLA follows Newtonian flow [31]. Mechanical properties of PLA align to that of the PET plastic and it can be precursor to produce bioplastics through all the polymer processing techniques like injection, extrusion, and blow molding. All the conventional polymer processing techniques is possible with PLA with minimal modifications [32]. Further, it also resembles the barrier properties of PET against organic permeants. Using barrier properties, most common processing technique involves the melt processing by which they are processed and shaped to desired from lowering their melting temperature including disposable cutlery is, melt spun fibers for textiles, bottles etc. However, drying is a key factor in PLA production with 4 hours of standard desiccant drying conditions at $45^{\circ} \mathrm{C}$ for amorphous PLA and of 2 hours at $60^{\circ} \mathrm{C}$ for crystalline PLA. Thermal degradation is also one of its processing con- 
straints [33].

\subsection{Starch}

Starch is inherently reported as one of the largest natural polymers known. Even though the first development of starch based biodegradable plastics date back to 1970 's, its coherent water susceptibility held down it being a top-notch research field. However, the need for environmentally friendly products have steered the research ranging from plant physiology to its plastic product performance. Being a major reserve material for polysaccharides, it is present in the photosynthetic tissues in plants storages like seeds, roots, tubers. Further, it is also the principal source of dietary calories to human populations. Amylose (25\%) and amylopectin (75\%) forms its main two polysaccharide components with very small concentrations of lipids and proteins [34]. They differ in the composition and are diverse in their properties, characteristics and molecular structure depending on their sources. With 1 - 4 linked d glucose units and molecular weight as high as 10 million, amylose forms a predominantly linear polysaccharide. With same backbone but molecular weight around 50 million and 5\% 1 - 6 linked branches, amylopectin is a very highly branched polysaccharide. The structures ofamylose and amylopectin are shown in Figure 1.

The decomposition temperature of starch $\left(200^{\circ} \mathrm{C}-220^{\circ} \mathrm{C}\right)$ is lesser than its melting temperature $\left(240^{\circ} \mathrm{C}\right)$ and therefore starch cannot be reprocessed into polymers in its native starch granules form. Modifications are this required before processing. To be duly processible, gelatinization needs to be carried out [35]. Breakdown of inherent multilevel structures present in starch is referred to as the gelatinization. A phase transition occurs from an ordered granular structure into a disordered state when the starch granules are heated in water due to elimination of the semi-crystalline region. As reported in literature [36] alternating amorphous and semi crystalline shells are first seen, that develops into lamellas and end up as macromolecular chains. $15 \%$ - 45\% crystallinity is generally seen in starch polymer systems. During extrusion processes, the water acts as a volatile plasticizer in thermomechanical input and starch is thus gelatinized and de structured [37]. The starch so obtained is referred to as the Thermoplastic starch (TPS) which is in huge demand for varied applications.
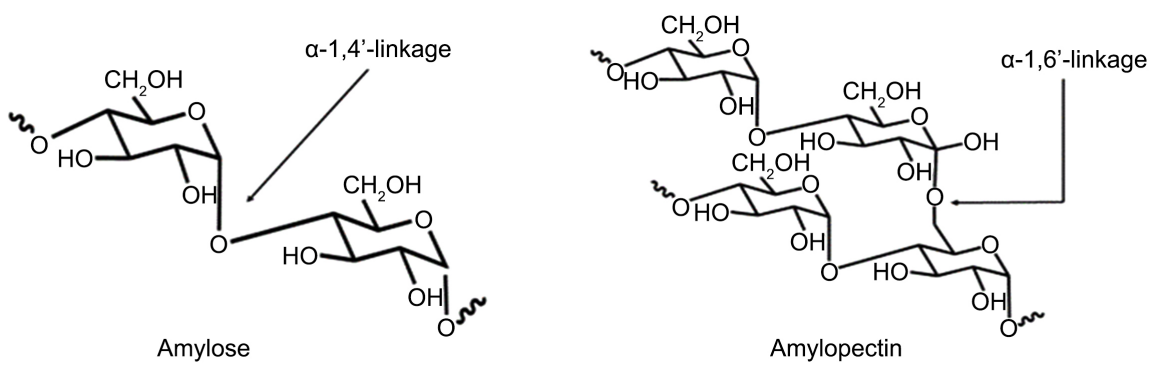

Figure 1. Chemical structure of Amylose and Amylopectin [32]. Source: Datta R, Henry M. Lactic acid: recent advances in products, processes, and technologies-a review. J Chem Technol Biotechnol 2006; 81: 1119-29. 
TPS can be produced from starch, corn, potato, rice, oils etc. and can be implemented into bioplastics through the common polymer processing techniques with few plasticizers like water and glycerol etc. Some of the preprocessing auxiliary processes include steeping of cleaned corn, evaporation, Sulphur dioxide addition, germ separation, drying and storage in silo. The sources from which TPS can be processed is innumerous owing to the vast and widespread availability of starch content in many of the naturally occurring resources. Potato, cassava, corn, rice, jackfruit, carrageen's, roots, and tubers are just few of the areas extensively researched upon. The following discussion pans around all such sources reported and its characteristics in each system [37].

Jackfruit is a tree of moraceae family commonly found in tropical and subtropical regions in India, Bangladesh, and southeast Asia. Among the 500 seeds in a single fruit, starch content amounts to 15\% [38]. High amylose content 30\% is reported. It has higher gelatinization temperature and thermomechanical shear tolerance as compared to potato and corn starches [38]. Using casting technique, film of thickness 0.099 to $0.155 \mathrm{~mm}$ was produced with different concentrations of glycerol as plasticizer. Some of the features observed included Low opacity, relatively high mechanical stability, and moderate water vapor permeability (WVP) [39]. Rice is another low-cost starch resource (90\%) serving as a principle staple of half of the world population [40]. During processing of rice, broken entities constitute the rice flour which are processed into biodegradable films by various researchers [41]. Using casting technique and sorbitol and glycerol as plasticizers, films were produced. It was observed to have compact structures, with similar mechanical properties and higher WVP with sorbitol (almost double) as compared to other starch films [42]. Citric acid and pectin are also used as plasticizers [43]. Biodegrability and mechanical properties were comparatively increased using citric acid as plasticizers (48.7\% in 15 days). However, it reduced the water absorption and water solubility [44]. Mixing of rice starch with kappa carrageenan's increased the hygroscopic properties and transparency to that of normal rice starch films. Possibility of edible films using the same approach are also reported [45]. Potato is also one of the key sources from which starch can be extracted. It is carried out through alkali, water or enzymatic extraction method and the bioplastic film was produced from it in a single screw extruder (SSE) as reported [46]. It showed similar properties as compared to the other starch films with enhanced load resistance [47]. Biodegradable Films can also be prepared using cassava starch, raw and acetylated using thermo-pressing [49] technique. It is reported to have comparative properties as that of other starch films. However, films made from raw cassava starch showed higher transparency and traction to friction in addition to a non-sticky, shining and transparent film [48].

Apart from edible starch sources, Nonedible roots and tubers can be a viable source for starch extraction [50]. Examples include oyster mushroom, dioscoreavillosa (wild sweet yam), Icacinatrichantha (false yam), Caladium bicolor 
(wild cocoyam) with 49.3\%, 59.4\%, 82.8\%, 86.7\% starch content and gelatinization temperature of $77,71,80,81$ respectively [51]. High percentage of amylose was seen in false yam (40.2\%) and oyster mushroom (56.7\%), higher than of cassava starch reported (31.2\%) [51]. Further, higher amylose consecration was seen in wild cocoyam (88.9\%) and wild sweet yam (84.6\%). Highest amylose content variant showed the best properties for packaging applications [52]. Some literature even shows the venturing into animal fat and lipids [53] in addition to the protein resins, plant lignin and cellulose for bio-plastic production. Using biosynthetic routes for genetically modified starch are also possible but the regulations are very stringent and limits its applicability [54]. The multifaceted requirements in polymers used in specialty applications poses number of changes and constraints [55]. Starch extraction from the abovesaid natural resources are possible and can be processed into bioplastics. The scrutinization process depends upon the product application, cost, viable and available technology options, and performance requirements. In USA, starch is primarily extracted from corn sources [56].

\section{Processing}

Processing of starch-based polymer, initially into TPE by plasticizers, followed by extrusion process is both challenging and demanding sector. Wide availability, low cost and total compossibility without any toxic wastes are few of its advantages [57]. Fermentation using biological routes are also seen to have application in addition to wet million process. However, extrusion remains the best processing technique for starch polymers as opposed to the injection molding and other methods of processing.

In this review, bioplastic films manufacturing via blown film extrusion is majorly focused upon. Among the various factors that affect the polymeric materials properties, Molecular weight, viscosity, and crystallinity are critical factors. Polymer chemistry and molecular structure coupled with bubble geometry in blown film extrusion influences final film properties like clarity, impact toughness and tensile strength. Polyethylene (PE) is majorly used for blown film applications amongst various other polymers. PE is easy to extrude and has good heat seal properties [58]. Few other polymers commonly used for such end applications include PP, Ethylene Vinyl Acetate (EVA), Ethylene vinyl alcohol $(\mathrm{EVOH})$, Polyvinylidene acetate (PVDA) etc. They have specific traits and are used for highly specialized applications. EVOH films offers better oxygen permeation resistance and EVA films offers better adhesion between layers. Addition of additives is also commonplace in blown film extrusion [59]. Anti-blocking agents (Diatomaceous earth), Antioxidants, antistatic agents (Amines), colorants (dry/liquid, color concentrates), lubricants (polymer processing aids PPAs), Reinforcements, fillers (mica, clay), stabilizers and Tackifiers (Polyisobutylene PIB) are the commonly used additives to enhance and modify species polymer and film properties. During extrusion plasticizers avoids the starch degradation, aides 
in gelation, decreases the processing temperature, increase the inter chain reactions, reduces the glass transition of the polymers formed and reduces the polymer interactions [60] [61]. Polysaccharide nanofillers improved material properties and nanoclay-based nano-bio composites provided matrix reinforcement [62]. Most effective characterization methods were Nuclear magnetic resonance NMR technique using diverse experiments on possible magnetic resonance [63] in starch-based evaluation of varied amylopectin and amylose content.

Testing properties of the extrudate on the initial runs are very important in optimization of product performance [64]. Several primary experiments are carried out in shear and no shear conditions with low moisture content and shear stresses for arriving and estimating a time needed to achieve steady molten starch phase for practical industrial applications [65] [66]. Plasticized starch was also observed to have shear thinning behavior with decreasing viscosity on increasing shear rates and followed a power-law expression as described below [67].

$$
\mathrm{K}=\mathrm{K} 0 \exp (\mathrm{E} / \mathrm{RT}-\alpha \mathrm{MC}-\alpha \mathrm{GC}-\beta \mathrm{SME})
$$

where $\mathrm{MC}$ is the moisture content, GC is the Glycerol content, and SME is specific mechanical energy, $\mathrm{T}$ is temperature, $\mathrm{E} / \mathrm{R}$ is reduced flow activation energy and $\mathrm{K} 0, \alpha, \beta$ are coefficients that are used in the power law equation. To formulate starch products effectively we need to discuss structure property relationship studies reported. Unfortunately, many of these studies have characterized succinctly or lack to state the proper test conditions to reproduce it. Nevertheless, few of the studies does help us to note few key observations. Higher strength and stiffness are seen in high amylose materials as compared to the high amylopectin materials [68]. It shows that the polymer networking is a key factor. Among the various starch modifications techniques reported in the literature, a few are discussed here, with potential to major repercussions in the industry. Amylose amylopectin ratio modifications is the most common. It is depictive of functional and granular properties like crystallinity, viscosity, and swelling power [69] [70]. This ratio also affects the thermal properties like the energy intake, viscosity increase extent and transition temperature in gelatinization process [71]. A reduction in rapid Visco analyzer (RPA) peak viscosity and breakdown values were observed in high amylose starch. A decrease in crystallinity and structural ordered of starch (double helix content) was observed due to the increase in the starch content [72]. Mainly, during extrusion there are two mechanism that polymer melt undergoes. It includes pressure flow and drag flow. Pressure flow occurs when there is pressure variation between one end of the channel to other inside a die and shear forces occurs during melt flow in extrusion [73]. When there is an acceleration of melt along a flow stream, it is referred to as elongation or stretching flow. In a blown film extrusion, this flow is more prevalent as it occurs when the melt is emerging from a die and is simultaneously pulled by the haul off equipment [74]. Various parameters influence the viscosity of the polymer during this processing. Higher temperature increases the kinetic energy and 
melt viscosity of the system. Further, at higher shear rates, increased shear rate also increases the melt viscosity. Molecular structure like molecular weight, molecular weight distribution and chain branching also influences the melt rheology. Elongation viscosity increases with molecular weight at a given stress. Long chain branches (LCB) gives rise to elongational thickening [75]. This phenomenon is a notable characteristic of blown film extrusion as it is directly related to having good melt strength. Melt strength is defined as the ability to pull the melt from die as a bubble, without thinning out or tearing apart. It is a precursor to overall bubble stability. Other key factors to consider includes the shear viscosity in the processing profile, a good mixing element (distributive or dissociative), screw design, branching and elongation viscosity of the polymer to be processed [76]. Few basic polymer tests are required for a proper profile creation. Density measurements are critical in an extrusion process as bulk density determines probability of potential feed problems. Melt density in the extruder and solid polymer density are also measured. Density-part cost relationship is necessary to design a cheaper product. Melt flow index or rate (MFI/MFR) gives different melt viscosity under a constant load and low shear rates. Universal testing machine (UTM) is generally used for testing tensile properties measuring the deformation resistance to stretching or pulling [77]. Measurements results include tensile modulus which is the ratio of stress to strain, elongation at break, elongation at failure. Strength at yield and failure, toughness etc. using the stress strain curves are also generated by UTM. Flexural tests using UTM measures the bending resistance and is more important to a plastic part required to or support or absorb load like that of the plastic rod or bumper beam. Heat deflection temperature measures heat resistance and temperature where specimen deforms. Further, long term heat aging, time-temperature tests, impact tests using Izod and Charpy tests methods are basic tests performed. There are stated processing recommendations for various resin systems as a generic guideline prior to processing.

\subsection{Extrusion}

In an integrated process of extrusion of polymeric materials into finished products, extrusion is one of the components of the entire line. By far, it is the most important and extensively used processing technique. Usually, TPS is manufactured by adding the starch source (corn, potato, tapioca) into the gravimetric feeder and then compounding through SSE [78]. Any extruder generally has five major equipment components. It comprises of the drive system, feed system, screw, barrel and heaters system, head and die assembly and the control system. Each component has specific and distinct role to play in the entire process [79] [80]. Biopolymers are hygroscopic and require the need of auxiliary equipment to carry out the drying process. This is crucial as the undesirable moisture in the extrusion temperature can degrade these polymers into lower molecular weight. It leads to defects like holes, splay and thus deteriorates the performance proper- 
ties. In shaping and drawing process, some important factors to consider are the draw ratio and the cooling rates. Draw ratio is directly related to the molecular orientation which imparts higher tensile and flexural properties in machine direction as compared to the transverse position [81]. Power required to heat the polymer to the molten state from the feed throat can be calculated by the following equation. $\mathrm{P}=\mathrm{mCp} \Delta \mathrm{T}+\mathrm{m} \Delta$ Hfusion where $\mathrm{m}$ is the mass flow rate in kilograms per hour, $\Delta \mathrm{T}$ is the difference in temperature between the melt temperature and feed in degree Celsius, $\mathrm{Cp}$ is the heat capacity in kilojoules per kilogram per degree Celsius and $\Delta$ Hfusion is the heat of fusion in kilojoules per kilogram for the polymer matrix. The SME was calculated as described by Leroy et al. [82] as follows: $\mathrm{SME}=\int \mathrm{T} 2 \pi \mathrm{n} / \mathrm{M} 60 \mathrm{dt}$ where, $\mathrm{n}$ is the screw speed in $\mathrm{rpm}, \mathrm{T}$ is the torque signal at mixing time $t$ and $M$ is the loaded mass.

Many auxiliary equipment's are in place for extrusion process like that of blending systems including ribbon blender, twin cone blender etc. different feeders including disk and vane feeder, drying equipment's (oven drying, hopper dryers and central lone, screen changers, gear pumps, granulators, chillers and heaters [83]. During extrusion of PLA, with a melt temperature over 179a screw $\mathrm{L} / \mathrm{D}$ ratio of $24-30$ and compression ratio of $2-3$, it was reported to give the best re-results [84]. Though limited by high production cost, PLA bottles are manufactured by the injection stretch blow molding techniques ISBM [85]. PLA sheets and films are manufacturing by casting processing with higher roller temperatures of $25^{\circ} \mathrm{C}-50^{\circ} \mathrm{C}$ and is reported to have higher surface energy $(38$ dynes $(\mathrm{cm}$ ) as compared to the polyolefins films [86] Extrusion blow molding with BUR ratio 2:1 - 4:1 and die temperature of 190 - 200'cis also a common processing technique for PLA films. However, use of viscosity enhancers are required to increase their lower melt strength [87]. PLA fibers by dry or melt spinning process are also used for increasing the breathability of a dress owing to their higher water vapor transmission [88]. Blending of PLA is widely incorporated owing to the reduction of costs and enhancing properties like flexibility, toughness, bursting strength and tear strength (garbage bags) [89]. Elastomer, TPS, PEG, tributyl citrate are just few of the examples [90].

Both single screw extruder (SSE) and Twin-screw extruder (TSE) can be used for starch-based polymer processing. If two extruder system is to be designed, SSE is better in the second run as it can handle the high viscosity of starch polymers and TSE can be used for raw starch because of its self-wiping capability [91]. Reactive extrusion process is also gaining demand rapid production rates and high conversion efficiency [92]. TPS is also reported to have processed using twin micro-compounder having a conical twin screw extruder at $105^{\prime} \mathrm{C}$ and 100 rpm screw speed [93]. In terms of processing of starch by extrusion or commonly referred to as extrusion cooking by some industry, the water solubility index (WSI) and the water absorption index (WAI) are two key factors for technological assessment of extrudates [94]. WAI was reported to increase with temperature rise in the barrel with maxima at $180^{\circ} \mathrm{C}$ to $200^{\circ} \mathrm{C}$ over which, WSI 
increased and WAI dropped. Compared to the wheat and corn starch, potato starch required lower melting temperature [95]. For initiation of melting, maximum torque recorded was $80^{\circ} \mathrm{C}-95^{\circ} \mathrm{C}$ for corn starch-glycerol mixtures, $78^{\circ} \mathrm{C}$ $88^{\circ} \mathrm{C}$ for potato starch-glycerol mixtures and $78^{\circ} \mathrm{C}-91^{\circ} \mathrm{C}$ for wheat starch-glycerol mixtures mixed under $80 \mathrm{rpm}$. It also majorly depended on water content in the specific samples [96]. Among the various studies conducted, with PASQUETTI, an Italian design TSE with $\mathrm{L} / \mathrm{D}=5$ screws diameter $-45 \mathrm{~mm}$, temperature of extrusion $80^{\circ} \mathrm{C}$ and $140^{\circ} \mathrm{C}$; pressure between $10 \mathrm{MPa}$ and $18 \mathrm{MPa}$, TPS pellets were processed and further sent to injection molding process with The injection speed of $0.07-0.09 \mathrm{~ms}^{-1}$, injection time-3 s, and temperature between $100^{\circ} \mathrm{C}$ to $180^{\circ} \mathrm{C}$ [97] Department of Food Process Engineering, Lublin University of Life Science (PL) also conducted a study with screw plastic extruder of L/D = 35 by SAVO Ltd Co., Poland. Later it was sent though a blown film process and Tg of obtained product was $132^{\circ} \mathrm{C}$ for $15 \%$ glycerol and at glycerol level of $30 \%$, the lowest temperature of $18^{\circ} \mathrm{C}$ was reported [98]. Extrusion cooking is also used in making starch-based foam materials for packaging during transportation. An SSE of $L / D=12$, temperature profile $80-140$ and screw rpm $100-130$, circular die of $5 \mathrm{~mm}$ internal diameter was used in the process [99]. Among combinations of starches and foaming agents used, potato starches with poly(vinyl) alcohol PVA and Plastron foam PDE as foaming agents showed the best results in terms of cutting and compression tests [100]. Further, increased screw speeds were seen to be more favorable. Higher efficiency and lower energy were required when potato starch was used with optimum screw speed of $100 \mathrm{rpm}$ [101].

Extrusion coating can also be regarded as one application of starch-based polymers. From the literature reported, high extrusion coating line speeds can be executed to make thin narrow necking coatings with good pinhole resistance and better heat-sealing performances [102]. However, the WVBP, and adhesion between starch and paper layer was observed to be inferior with a cracking tendency which limits its applications [103]. As discussed, special considerations are prerequisite for using conventional processing equipment to be used for biopolymer processing. Such a study was reported for blown film and thermoforming process with PLA, PBS. A Duck bill die design to minimize sag between die exit and primary gap of a roll, high output barrier screw and lower melt temperature are few of the modifications implemented. Higher structural damages are accompanied with higher SME [104]. High level of plasticizer increased the ease of disentanglement and decreased the density of the polymer entanglements. Further higher temperature increased the polymer chain mobility. Many rheological studies were carried out using a slit die viscometer attached to the single screw extruder [105]. Strong shear thinning behavior was seen when the glycerol water mixture was increased [106]. Amylose content increase also exhibited a similar behavior. Natural polyols like sorbitol and glycerol are also reported to be used as plasticizer in the starch systems [107]. Further discussion 
span around blown film process and attributes if its design.

\subsection{Blown Film Extrusion}

One of the most significant among the various polymer processing techniques is blown film extrusion. Films are used as garbage bags, grocery sacks and in flexible packaging. To make thermoplastic film in large volumes, blown film process is widely used and are coupled commonly with single screw extruders. One of the striking factors of this process is that different diameter bubble can be blown from the very same die. The entire layout of the process involves the upstream components, grooved feed throat, screw, blown film dies, bubble geometry, cooling and stabilization, collapsing frames, haul off, winders, treatment and control. These factors need to be discussed individually to understand the design concepts associated with the film processing. Maximum extrusion throughput with minimal dimensional variations is the most vital factor be considered for blown film system components. Crammer feeder can be used to grind the polymer feed into a fluff to maintain constant feed pressure [108]. For blown film, grooved feed throats are used in common. Grooved feed throat with helical grooves machined into it increase the throughput. It also increases conveyance rate of the polymer melt by minimizing feed/screw friction and maximizing feed/barrel friction. Coupled with such a feed throat, usually a screw with low compression ratio is used $(<1)$. Since high viscosity polymer with high viscosity are processed, barrier flight is also used to prevent unmelts formation. There are also auxiliary set ups for bubble stabilization (cages/irises), pre-flattening frames (collapsing frames), haul off (to pull the film up from die) and winders to collect the roll processed out [109]. In such a case, alterations like lower compression ratio, good thermal barrier, high pressures and excellent feed throat is necessary. Compression ratio is defined as the feed channel depth divided by the meter channel depth. The extrude can flow through an annular die and as the polymer is cooled, it forms a bubble or a tube which is vertically pulled away from the die [110]. The schematic representation is shown by the Figure 2 below.
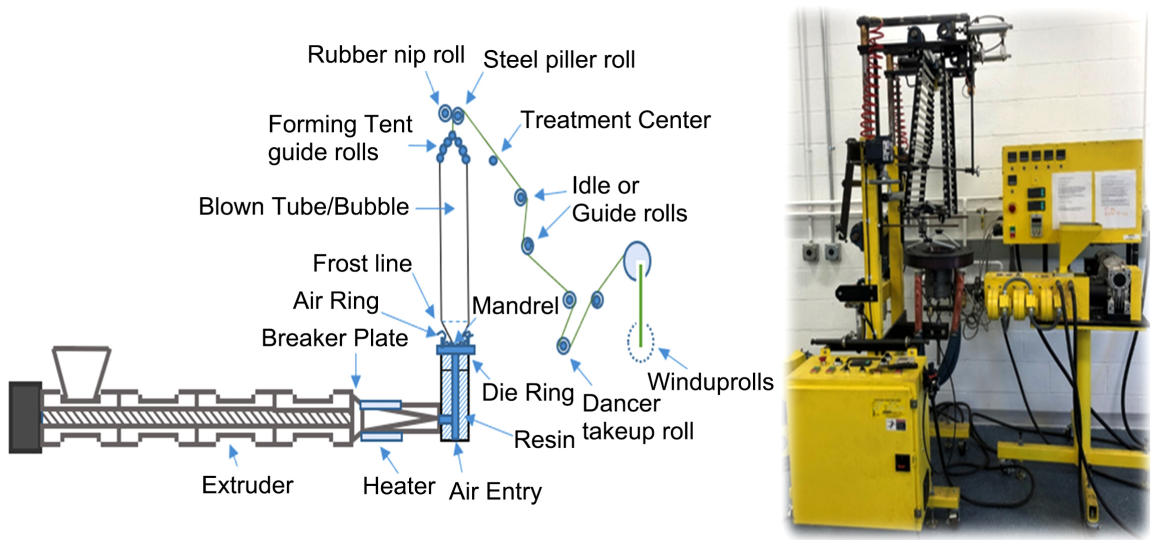

Figure 2. Schematic Representation of a Blown Film Extruder and its lab scale model. 
An air ring and internal bubble cooling solidifies the polymer melt. Film speed, air flow and temperature difference usually determine the cooling rate. For gauge control and uniformity, bubble stability is a key factor. Once is it cooled, Bubble collapses in the forming tent using nip rolls simultaneously followed by puller rolls. Nip rollers stretch the melt in the machine direction and internal air pressure stretches the melt in a transverse direction. Usually a section called the treatment center is added between the rolls and winder to modify polymer surface polarity, for better adhesion. It depends on the slitting, lay flat and two lay flat widths are attainable.

Lower MFI resins are used in blown film process with lower melt temperature and bubble stability, cooling air temperature, frost line height, bubble sizing gage and collapsing frame, winder, tension control and air flow are all critical parameters to be considered [111]. As discussed in earlier sections extruder throughout is dependent on tower height, extruder capacity and resin melt temperature. Air entering the bubble replaces air leaving the bubble once bubble is properly inflated to maintain constant pressure within the bubble. Point where the film changes to solid state from the melt exit, or the distance from die face to the point where solidification takes place is called the frostline height. Bubble diameter divided by the die diameter meeting the bubble expansion in the transverse direction gives us the blow-up ratio (BUR). Collapsed bubble width before slitting is the Lay flat width (LFW) and drawing in the machine direction in the film tower is referred to as the drawdown ratio (DDR). Larger blow up ratio would mean higher is the molecular orientation in the transverse direction with decrease in drawdown ration [112]. Time required for the film to travel to the frost line from the die exit is referred to as the time frame for expansion. Tensile properties, toughness, flexural strength, optical properties are all affected by the BUR. Take up ratio (TUR) is the ratio of film velocity to that of melt viscosity. It is an indication of molecular orientation and amount of stretching in machine direction and its always greater than 1 .

Addition bubble geometry variables include die diameter, die gap, stalk, bubble diameter (BD) and film thickness. Initial bubble diameter leaving the die is the die diameter and initial bubble wall thickness is referred to as the die gap. As the die exits the die gap; the upward velocity is referred to as melt speed and the velocity of polymer through nip rollers are referred to as the nip speed. The amount of air contained inside the bubble between die gap and nip rollers, known as internal bubble pressure/internal bubble volume along with the nip, melt speed and the cooling rate determines die geometry [113]. Generally, two types of bubble shapes are selected for polymer processing depending on its intrinsic properties, pocket bubble and high/long stalk bubble. While the former shape is used for polymers having higher melt strength (HDPE) while the latter is used for polymers having lower melt strength (LDPE). This way, until the polymer reaches a lower temperature, TD stretching is delayed and thus increases bubble stability. This is highly relevant in starch-based bioplastic film or a bioplastic film in gen- 
eral because they exhibit low melt strength. Among the line control, necessary and accurate measurements of melt quality, film thickness, LFW, Frost line height need to be done for property consistency and process uniformity. Laser gauges, thickness gauges and even online infrared temperature measurement systems are used in industry currently [114]. A balance is required between the molecular orientation in the transverse and machine directions. A lower degree of branching in the polymer gives an easier draw down and lower density materials are harder to wind. Low molecular weight fraction results in a higher melt temperature and lesser throughout. Further, high molecular weight fraction helps in easier draw down but with lower bubble stability [115].

Biaxial orientation and Capability of multi-layer high barrier properties for food packaging are key traits of blown film process. With the common expansion ratio between 1.5 to 4 times the diameter, draw down ratio is controlled by changing the haul off speed forming a film in both the MD directions with comparatively better properties [116]. In this process, PE is the most common resin used along with PP, PA, EVOH etc. They are used with special adhesives resin called tire layers for better gelling between layers. Industrial, consumer, agricultural, lamination and barrier packaging are all the areas served by the films so produced. In a critic review, it will be right to say that the low cost and process flexibility are its positive traits while size variances and product limitations are its constraints [117]. Four main functions constitute the bag making process which involves feeding of the material, sealing, cutting and stacking. Compounded TPS pellets can then be blown into a film at a blow-up ratio of 2 3 with 45 parts glycerol per 100 parts dry starch and 13 weight\% moisture [118]. The compact extruder used was characterized by a $19 \mathrm{~mm}$ diameter and length of 25D.

Injection molding is possible with TPS at barrel temperatures between $100^{\circ} \mathrm{C}$ and $180^{\circ} \mathrm{C}$ [119]. Few advantages of this process are the lesser scarp, lower cost of equipment, one die for many widths and good balance between transverse and machine directions. Bags can be effectively manufactured and only one heat seal at the bag bottom required [120]. It's an advantage over cast film process as it generally requires three heat seals. Since take off equipment is above extruder, they are usually kept very close to the floor and more space for cooling is attained and the dies are usually by roll around casts with die entrance on the bottom. Co-extrusion is also getting global acclaimed wherein multiple polymer melt streams are extruded out from a single die using concentric or stack coextrusion dies. The final applications are in breathable packaging, shrink film and high barrier films. Double bubble system with lower TUR and BUR is used for extruding PVDC polymer as it gives higher molecular orientation [121].

The Polymer Analysis and Simulation Software (PASS@) die flow collection [122] provides a way to simulate three commonly used industrial dies, the spiral blown film die, the mandrel pipe die, and the coat-hanger sheet or film die. Blown film dies are predominantly constituted by using The Spiral Die Simula- 
tion. is extremely critical in film blowing, delivering a homogenous melt property is greatly amplified through this process. A circular mandrel surrounded by a die body is visualized as a typical spiral mandrel. Further, blown film extrusion simulator by author Kirk cantor also serves as an excellent resource to get acquainted with the blown film processing and its intricate process effects on the final film.

\section{Polymer Blends Based on Bio Sources}

Among the TPS/Blend study, PLA was widely researched upon. TPS/PLA blended biopolymers were studied in terms of viscosity and temperature rise by $100-900$ $\mathrm{s}^{-1}$ shear rate and temperatures $\left(100^{\circ} \mathrm{C}-180^{\circ} \mathrm{C}\right)$ and screw speed between 50 and $250 \mathrm{~min}$ a lab scale TSE and with and without additives. It was observed that viscosity increased between $120^{\circ} \mathrm{C}$ and $140^{\circ} \mathrm{C}$ and then a decrease was seen between $140^{\circ} \mathrm{C}$ and $160^{\circ} \mathrm{C}$, finalizing the plasticization temperature to be after $140^{\circ} \mathrm{C}$ [123]. PLA with compatibilizer enhances the shock resistance and shock absorption capability and is reported to have been used by Mazda Corp in the car parts of the RE Hybrid variant. PVA is also widely used as a blending component with many starch sources like cassava, potato starch plasticized with glycerol, urea etc. With a TSE having $20 \mathrm{~mm}$ screw diameter, $100 \mathrm{rpm}$ screw speed and temperature between 90 to 200 [124]. In films with higher PVA content, lower opacity $23.8 \%$ to $42.9 \%$, higher thermal stability and lower WVP were observed whereas higher glycerol showed to be detrimental to the film properties [125]. Critically reviewing the properties, we observe tensile strength of 2.6 - 11 MPA in case of Cassava starch/PVA as compared to 8 - 13 MPA in potato starch/ PVA and 70 TO 20 MPA in maize starch/PVA (10 - 40 WT\%) films without plasticizers. Regarding the elongation at break, Cassava starch/PVA ranged from $377 \%-698 \%$ to $94 \%-398 \%$ in potato starch/PVA to $7 \%-48 \%$ maize starch /PVA blends [126]. Tapioca/PVA/PHA blends have been studied by melt extrusion with Maleic anhydride as an added component. With $10.14 \%$ maleic anhydride, $20.13 \%$ tapioca starch content and a $41.3 \mathrm{rpm}$ screw speed, films of 16.4 MPa tensile strength and $13.2 \%$ elongation at break was obtained with $30.94 \%$ water absorption. It was observed that increased MA content reduced WAI.

\section{LCA Analysis and Testing Involved}

Among the comparison of LCA analysis of PLA, PHA and TPS per kilogram, PHA exhibit a 50 GJ of energy, PLA 67.8 GJ and TPS with 48.3 GJ of energy (Figure 3) [127]. In terms of carbon dioxide equivalence, PHA EXHIBITS A $0.26 \mathrm{~kg} \mathrm{CO}_{2}$ equivalence whereas PLA exhibit $1.24 \mathrm{CO}_{2}$ equivalence and TPS exhibits $3.3 \mathrm{CO}_{2}$ equivalence [128]. PLA LCA are reported extensively, however, very limited information is available in the LCA analysis of PHA and TPS Bioplastic production. LCA can be beneficial tool to evaluate the environmental impacts of Bioplastic derived from PLA [129] [130]. An LCA cradle to grave analysis on PLA pellets branded as Ingeo ${ }^{\circledR}$ PLA is reported in the literature. Pollution, 


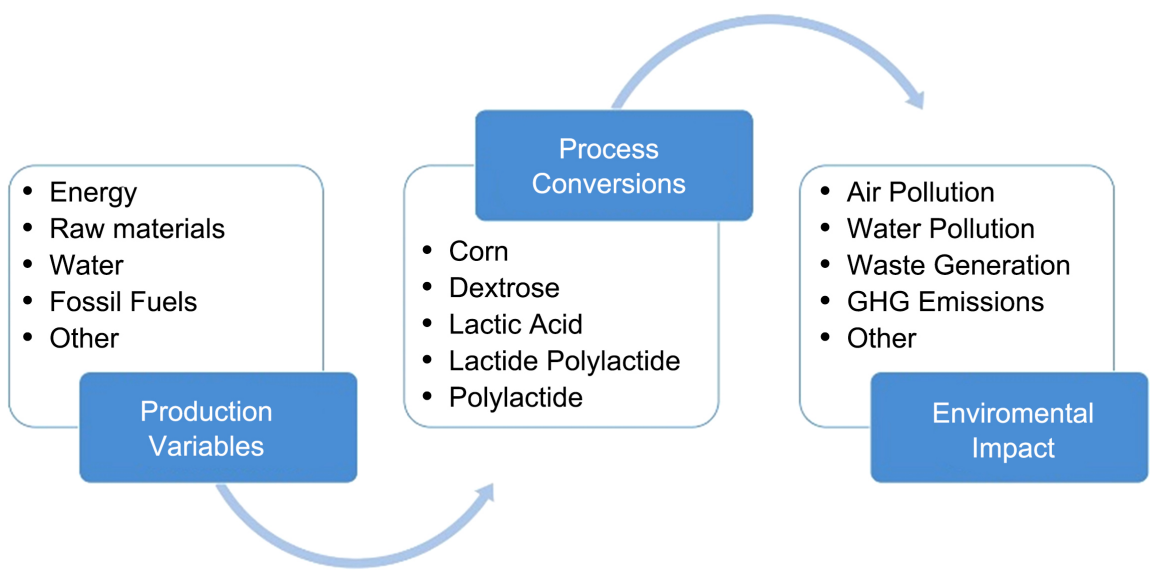

Figure 3. Factors evaluated in an LCA for PLA Production. Source: Sustainable Plastics: Environmental Assessments of Biobased, Biodegradable, and Recycled Plastics, First Edition. Joseph P. Greene. (C) 2014 John Wiley \& Sons, Inc. Published 2014 by John Wiley \& Sons, Inc.

waste generation and gas emotions were critically evaluated in this LCA. In all above-mentioned processes there is electricity, steam, water, fossil fuels and other materials usage and ISO 14,040, 14,044 was followed for the LCA. To produce $1 \mathrm{~kg}$ of the product, $0.06784 \mathrm{GJ}$ energy was consumed with Carbon footprint being $1.24 \mathrm{~kg}$ carbon dioxide equivalent. $0.267 \mathrm{~kg}$ of solid waste was generated and $48.78 \mathrm{~L}$ water was consumed.

Few of the film performance tests are discussed which needs to be satisfied for a blown film. Tensile strength and elongation (ASTM D882) are tested in Universal Testing Machine and helps to evaluate the load carrying and stretching capacity respectively. Tear strength (ASTM D1104, D1922) provides us the information on resistance to initiate of a tear or its propagation. In Impact resistance (ASTM D1709, D3420) tests, perpendicular loads are applied to the pane of film in both MD and TD. Stickiness in film can cause handling difficulties and inconvenience, and thus blocking load (ASTM D3354) and friction coefficient te4sts (D 1894) are very important. Small, hard globules occurring in film are referred to as gel (fisheyes) and they act as stress concentration points. Tests (D D351 and D3596) are utilized to measure the count. Some blown films require to be effective in low temperatures in refrigerators (food packaging) or in outer atmosphere (space) applications, thus the low temperature brittleness tests (ASTM D1790) are necessary. Further, basic film tests like gloss (ASTM D2457), transparency (ASTM D1746), haze (ASTM D 1003), density (ASTM D1505) are all measured. Regarding the viscosity of the polymer, Tests by capillary rheometer (ASTM D835) and Melt flow rate tests (ASTM D1238) showing the amount/ grams of melt extruded from it in 10 minutes are utilized [131].

\section{Future Aspects}

We have limited knowledge and literature available regarding the degradation mechanism of bio-plastic films in the environment. One such study carried out 
very recently reported the effects of plasticizers and weather on its degradation [132]. Degradation process involves the bio-assimilation of the polyesters which is simultaneously followed by a biotic hydrolysis. This can be carried out by microorganism present in the soil (bacteria, fungi, termites, and worms) and bioplastics are thus broken down [133]. This microbial uptake rate doubled the degradation rate if it was coupled with porous mist soils showing the effect of moisture in terms of rainfall, relative humidity etc. [134]. A glycerol plasticized cassava starch degraded within ten weeks (98.3\%) and in high concentration of water, it was disintegrated within 5 weeks (ASTM D3826-98) [135]. If we compare the plastic bags to the paper bag, the total energy required for manufacturing, water used, solid waste crated are all higher for paper bags [136]. There are well established ASTM and ISO standard which states that a specific biodegradable plastic should disintegrate sufficiently within 180 days of compositing in the specified conditions [137].

Another important application biopolymer has gained huge demand lately is for biomedical applications [138]. It is used as a coating for drug delivery and bioabsorbable medical device materials because of its non-toxicity and combability with human tissues. PLA, Polyglycolic acid (PGA), and Polycaprolactone (PCL) are the most common biopolymers used in medical devices [139]. Simple esters are formed through hydrolysis in a non-enzyme route and the polymers are later eliminated from body naturally via urine or normal cellular activity. PLA is widely used as a replacement to titanium plates, screws, and metallic implants [140]. It is bio-absorbable and do not erode into the bone structure. After a case of major bone fracture, it has majorly eliminated the need of a second surgery to take out the rod from the body [141]. PHA biopolymers has found its use scaffolding for arteries [142]. drug delivery and tissue engineering.

Nature works based in the USA is the largest producer of PLA in the world with a completely product certification [143]. Nova Mont from Italy is one of the most important players in the market producing blends of TPS and polycaprolactone in the bio plastic industry. Ceroplast is an American company having a 36,000 MT TPS facility in Indiana. BASF too has entered this arena with their starch bends called Eco flex. There is overall a surge in its production to 5800 thousand metric tons from a 200 thousand metric tons as reported in 2016 [144]. Plastic products heavy dependence upon fossil fuels is quite alarming. The persistence of plastic pollution and the abundant solid wastes aggravates the problem.

\section{Conclusions}

Among the various natural sources, Starch is the most versatile raw material for bioplastics with wide spectrum of products. Whereas PLA sources might have a potential competition with human and livestock feed supply chain, Starch sources can rely more on the low value byproduct wastes also. The performance parameters of such bioplastic films discussed are comparable to that the conventional 
plastic films. The negative impact due to lower melt strength is mitigated by the process design modifications. Further, in bioplastics, adjustments are also needed to accommodate barrier properties and brittleness. Using Polymer modifications, using specialized coatings and blending with other apt bio renewable resources are just few approaches to overcome the many challenges. Selection of the most appropriate source and technique for bioplastic processing depends on product performance, cost, available technological advancements, feasibility, sustainability etc.

The governments across the globe are imposing ban on single use plastic. Many deem them as the major reason for plastic pollution. In such a scenario, the growth of starch-based bio plastic is sure to happen at an exponential scale very fast. There is requirement of additional research in terms of customer needs focusing more on the starch sources, developing formulations for effective range of application with good processability and polymer degradability. Also, many dubious claims have come up in the industry misguiding biodegrability factor. It is prevalent in terms of the products where blends are used with petroleumbased products but claimed to be totally biodegradable. With the influx of these products, it mandatory to put in strong tests and law making sure that specifications are met and are environmentally safe. The advantages of Bioplastic are innumerous the major being environmental suitability and sustainable factor. Novelty of the research will arise once these shortcomings in bioplastic commercialization are overcome by new technologies and innovative advancements.

Further, we can also overview the extensive demand and supply of bioplastics all around the world portraying its very bright future. Such sustainable practices will conserve resources for future generations. Environmental substantiality with full thrust on polymer recycling and the use of bio renewable resources surely paves way to the next big revolution in plastic industry.

\section{Acknowledgements}

Bioplastics have always been one of my favorite topics. I would like to express my heartfelt thanks to Dr Joseph Greene of CSU, Chico, USA and my Professor, Dr. Vijaya Kumar of VNIT, India for inspiring me to research on this pertinent topic. I would also like to extend my gratitude to my friends and family who extended full support during my review preparation.

\section{Conflicts of Interest}

The author declares no conflicts of interest regarding the publication of this paper.

\section{References}

[1] WCED (World Commission on Environment Development) (1987) Our Common Future, World Commission on Environment and Development. Oxford University Press, Oxford. 
[2] Anastas, P. and Zimmerman, J. (2003) Design through the Twelve Principles of Green Engineering. Environmental Science \& Technology, 37, 94A-101A. https://doi.org/10.1021/es032373g

[3] McDonough, W., Braungart, M., Anastas, P.T. and Zimmerman, J.B. (2003) Applying the Principles of Green Engineering to Cradle-to-Cradle Design. Environmental Science and Technology, 37, 434A-441A. https://doi.org/10.1021/es0326322

[4] White, L. and Noble, B. (2013) Strategic Environmental Assessment for Sustainability: A Review of a Decade of Academic Research. Environmental Impact Assessment Review, 42, 60-66. https://doi.org/10.1016/j.eiar.2012.10.003

[5] Gerngross, T. and Slater, S. (2000) How Green Are Green Plastics? Scientific American. https://doi.org/10.1038/scientificamerican0800-36

[6] Chandra, R. and Rustgi, R. (2011) Biodegradation of Maleated Linear Low-Density Polyethylene and Starch Blends. Polymer Degradation and Stability, 56, 185-202. https://doi.org/10.1016/S0141-3910(96)00212-1

[7] European Commission, DG Environment (2011) BIO Intelligence Service, Plastic Waste in the Environment-Final Report.

[8] Halley, P.J., Truss, R.W., Markotsis, M.G., Chaleat, C., Russo, M., Sargent, A.L., et al. (2007) A Review of Biodegradable Thermoplastic Starch Polymers. In: Polymer Durability and Radiation Effects, American Chemical Society, Washington DC, Chapter 24, 287-300. https://doi.org/10.1021/bk-2007-0978.ch024

[9] Tom, L., Mark, R., Brenda, P., et al. (2009) Sustainable Biomaterials Collaborative, Guidelines for Sustainable Bioplastics, Volume 1.

[10] Bastioli, C. (2005) Starch-Based Technology. In: Bastioli, C., Ed., Handbook of Biodegradable Polymers, Rapra Technology Limited, Shawbury, 257-286.

[11] Patel, M., Bastioli, C., Marini, L. and Wurdinger, E. (2005) Life-Cycle Assessment of Bio-Based Polymers and Natural Fiber Composites. In: Biopolymers Online, Wiley, Hoboken, 272-291.

[12] BPI World (2013) BPI Certified Compostable Plastic Resins, Cutlery, Bags, and Packaging.

[13] Hunter, S., Pereira, B. and Helling, R. (2008) Life Cycle Assessment of Sugarcane Polyethylene. The DOW Chemical Company.

https://www.dow.com/-/media/dow/business-units/dow-us/energ-ice/109-52241

[14] Liu, Z. and Liang, J. (1999) Methanol to Olefin Conversion Catalyst. Current Opinion in Solid State \& Material Science, 4, 80-84. https://doi.org/10.1016/S1359-0286(99)80015-1

[15] Chavan, S., Srinivas, D. and Ratnasamy, P. (2001) Selective Oxidation of Para-Xylene to Terephthalic Acid by $\mu 3$-Oxo-Bridged Co/Mn Cluster Complexes Encapsulated in Zeolite-Y. Journal of Catalysis, 204, 409-419. https://doi.org/10.1006/jcat.2001.3385

[16] Penga, F., Rena, J., Xub, F., Bianb, J., Pengc, P. and Sun, R. (2010) Comparative Studies on the Physico-Chemical Properties of Hemicelluloses Obtained by DEAECellulose-52 Chromatography from Sugarcane Bagasse. Food Research International, 43, 683-693. https://doi.org/10.1016/j.foodres.2009.10.020

[17] Zhao, X., Wu, R. and Liu, D. (2011) Production of Pulp, Ethanol and Lignin from Sugarcane Bagasse by Alkali-Peracetic Acid Delignification. Biomass and Bioenergy, 35, 2874-2882. https://doi.org/10.1016/j.biombioe.2011.03.033

[18] Park, S. and Lee, S. (2005) Systems Biological Approach for the Production of Various Polyhydroxyalkanoates by Metabolically Engineered Escherichia coli. Macro- 
molecular Symposia, 224, 1-9. https://doi.org/10.1002/masy.200550601

[19] Qi, Z., Ye, H., Xu, J., Chen, J. and Guo, B. (2013) Improved the Thermal and Mechanical Properties of Poly(butylene succinate-co-butylene adipate) by Forming Nanocomposites with Attapulgite. Colloids and Surfaces A: Physicochemical and Engineering Aspects, 421, 109-117. https://doi.org/10.1016/j.colsurfa.2012.12.051

[20] Tan, L., Chen, Y., Ahou, W., Nie, H., Li, F. and He, X. (2010) Novel Poly(butylene succinate-co-lactic acid) Copolyesters: Synthesis, Crystallization, and Enzymatic Degradation. Polymer Degradation and Stability, 95, 1920-1927. https://doi.org/10.1016/j.polymdegradstab.2010.04.010

[21] Urakami, T., et al. (2000) Development of Biodegradable Plastic Poly-Beta Hydroxybutyrate/Polycaprolactone Blend Polymer. Kobunshi Ronbunshu, 57, 263. https://doi.org/10.1295/koron.57.263

[22] Greene, J. (2009) Biodegradable and Oxodegradable Plastics Degradation in Compost and Marine Environments. Proceedings of the 8 th World Congress of Chemical Engineering, Montreal, August 2009.

[23] Greene, J. (2013) PHA Biodegradable Blow-Molded Bottles: Compounding and Performance. Plastics Engineering, 69, 16-21. https://doi.org/10.1002/j.1941-9635.2013.tb00940.x

[24] Tianjin Biodegradable Plastics (2011) Green Bio from Tianjin.

[25] Wang, W.T., Zhang, H., Jia, R., Dai, Y.Y., Dong, H.Z., Hou, H.X. and Guo, Q.B. (2018) High Performance Extrusion Blown Starch/Polyvinyl Alcohol/Clay Nanocomposite Films. Food Hydrocolloids, 79, 534-543. https://doi.org/10.1016/j.foodhyd.2017.12.013

[26] Natureworks (2013) How Ingeo Is Made. https://www.natureworksllc.com/What-is-Ingeo/How-Ingeo-is-Made

[27] Shindo, S. and Tachibana, T. (2004) Production of L-Lactic Acid from Spent Grain, a By-Product of Beer Production. Journal of the Institute of Brewing, 110, 347-351. https://doi.org/10.1002/j.2050-0416.2004.tb00631.x

[28] Mussatto, S., Fernandes, M., Manciha, I. and Roberto, I. (2008) Effects of Medium Supplementation and $\mathrm{pH}$ Control on Lactic Acid Production from Brewer's Spent Grain. Biochemical Engineering Journal, 40, 437-444. https://doi.org/10.1016/j.bej.2008.01.013

[29] Auras, R., Harte, B. and Selke, S. (2004) An Overview of Polylactides as Packaging Materials. Macromolecular Bioscience, 4, 835-864. https://doi.org/10.1002/mabi.200400043

[30] Garlotta, D. (2001) A Literature Review of Poly(lactic acid). Journal of Polymers and the Environment, 9, 63-84. https://doi.org/10.1023/A:1020200822435

[31] Cooper-White, J.J. and Mackay, M.E. (1999) Rheological Properties of Poly(lactides). Effect of Molecular Weight and Temperature on the Viscoelasticity of Poly(l-lactic acid). Journal of Polymer Science Part B: Polymer Physics, 37, 1803-1814. https://doi.org/10.1002/(SICI)1099-0488(19990801)37:15<1803::AID-POLB5>3.0.C $\underline{\mathrm{O} ; 2-\mathrm{M}}$

[32] Datta, R. and Henry, M. (2006) Lactic Acid: Recent Advances in Products, Processes, and Technologies-A Review. Journal of Chemical Technology \& Biotechnology, 81, 1119-1129. https://doi.org/10.1002/jctb.1486

[33] Taubner, V. and Shishoo, R. (2001) Influence of Processing Parameters on the Degradation of Poly(l-lactide) during Extrusion. Journal of Applied Polymer Science, 79, 2128-2135. 
https://doi.org/10.1002/1097-4628(20010321)79:12<2128::AID-APP1020>3.0.CO;2-\#

[34] Song, J.H., Murphy, R.J., Narayan, R. and Davies, G.B.H. (2009) Biodegradable and Compostable Alternatives to Conventional Plastics. Philosophical Transactions of the Royal Society B, Biological Sciences, 364, 2127-2139.

https://doi.org/10.1098/rstb.2008.0289

[35] Westhoff, R.P., Otey, F.H., Mehltretter, C.L. and Russell, C.R. (1974) Starch-Filled Polyvinyl Chloride Plastics-Preparation and Evaluation. Industrial and Engineering Chemistry Product Research and Development, 13, 123-125. https://doi.org/10.1021/i360050a008

[36] Perez, S., Baldwin, P.M. and Gallant, D.J. (2004) Structural Features of Starch Granules I. In: James, B. and Roy, W., Eds., Starch, 3rd Edition, Academic Press, San Diego, Chapter 5.

[37] Averous, L. and Halley, P.J. (2009) Biocomposites Based on Plasticized Starch. Biofuels, Bioproducts and Biorefining, 3, 329-343. https://doi.org/10.1002/bbb.135

[38] Averous, L. (2004) Biodegradable Multiphase Systems Based on Plasticized Starch: A Review. Journal of Macromolecular Science Part C Polymer Reviews, 44, 231-274. https://doi.org/10.1081/MC-200029326

[39] Sagnelli, D., Hooshmand, K., Kemmer, G.C., et al. (2017) Cross-Linked Amylose Bio-Plastic: A Transgenic-Based Compostable Plastic Alternative. International Journal of Molecular Sciences, 18, 2075. https://doi.org/10.3390/ijms18102075

[40] Suryadevara, V., Lankapalli, S.R., Danda, L.H., Pendyala, P. and Katta, V. (2017) Studies on Jackfruit Seed Starch as a Novel Natural Superdisintegrant for the Design and Evaluation of Irbesartan Fast Dissolving Tablets. Integrative Medicine Research, 6, 280-291. https://doi.org/10.1016/j.imr.2017.04.001

[41] Rengsutthi, K. and Charoenrein, S. (2011) Physico-Chemical Properties of Jackfruit Seed Starch (Artocarpus heterophyllus) and Its Application as a Thickener and Stabilizer in Chilli Sauce. LWT-Food Science and Technology, 44, 1309-1313. https://doi.org/10.1016/j.lwt.2010.12.019

[42] Lopez, O.V. and Garcia, M.A. (2012) Starch Films from a Novel (Pachyrhizus ahipa) and Conventional Sources: Development and Characterization. Materials Science and Engineering. C, 32, 1931-1940. https://doi.org/10.1016/j.msec.2012.05.035

[43] Dias, A.B., Muller, C.M.O., Larotonda, F.D.S. and Laurindo, J.B. (2010) Biodegradable Films Based on Rice Starch and Rice Flour. Journal of Cereal Science, 51, 213-219. https://doi.org/10.1016/j.jcs.2009.11.014

[44] Zhou, Z., Robards, K., Helliwell, S. and Blanchard, C. (2002) Composition and Functional Properties of Rice. International Journal of Food Science \& Technology, 37, 849-868. https://doi.org/10.1046/j.1365-2621.2002.00625.x

[45] Mali, S., Sakanaka, L.S., Yamashita, F. and Grossmann, M.V.E. (2005) Water Sorption and Mechanical Properties of Cassava Starch Films and Their Relation to Plasticizing Effect. Carbohydrate Polymers, 60, 283-289.

https://doi.org/10.1016/j.carbpol.2005.01.003

[46] Mariappan Kadarkarainadar, M., Jawaid, M. and Asim, M. (2019) Corn and Rice Starch-Based Bio-Plastics as Alternative Packaging Materials. Fiber, 7, 32. https://doi.org/10.3390/fib7040032

[47] Gadhave, R.V., Das, A., Mahanwar, P.A. and Gadekar, P.T. (2018) Starch Based Bio-Plastics: The Future of Sustainable Packaging. Open Journal of Polymer Chemistry, 8, 21-33. https://doi.org/10.4236/ojpchem.2018.82003

[48] Larotonda, F., Hilliou, L., Sereno, A. and Gonçalves, M. (2005) Green Edible Films Obtained from Starch-Domestic Carrageenan Mixtures. 
[49] Sagnelli, D., Hebelstrup, K.H., Leroy, E., Rolland-Sabate, A., Guilois, S., Kirkensgaard, J.J.K., Mortensen, K., Lourdin, D. and Blennow, A. (2016) Plant-Crafted Starches for Bioplastics Production. Carbohydrate Polymers, 152, 398-408. https://doi.org/10.1016/j.carbpol.2016.07.039

[50] Mooney, B.P. (2009) The Second Green Revolution? Production of Plant-Based Biodegradable Plastics. Biochemical Journal, 418, 219-232. https://doi.org/10.1042/BJ20081769

[51] Cereda, M.P., Henrique, C.M., Oliveira, M.A., Ferraz, M.V. and Vicentini, N.V. (2000) Characterization of Edible Films of Cassava Starch by Electron Microscopy. Brazilian Journal of Food Technology, 3, 91-95.

[52] Narayan, R., Bloembergen, S. and Lathia, A. (1999) Method of Preparing Biodegradable Modified-Starch Moldable Products and Films. USA Patent No. 5,869,647.

[53] Alobi, N.O., Sunday, E.A., Magu, T.O., Oloko, G.O. and Nyong, B.E. (2017) Analysis of Starch from Non-Edible Root and Tubers as Sources of Raw Materials for the Synthesis of Biodegradable Starch Plastics. Journal of Basic and Applied Research, 3 , 27-32.

[54] Oladayo, O.O., Umunna, Q.C., Joseph, O.S. and Oluwasegun, W. (2016) Physicochemical Chemical Properties of Cassava Starch and Starch-Keratin Prepared Biofilm. Songklanakarin Journal of Science and Technology, 38, 349-355.

[55] Mojzoobi, M.R., Coonock, A.J., Hill, M.S. and Harding, S.E. (2003) Partial Fractionation of Wheat Starch Amylose and Amylopectin Using Zonal Ultra-Centrifugation. Carbohydrate Polymer, 52, 269-274. https://doi.org/10.1016/S0144-8617(02)00295-3

[56] Lusser, M., Parisi, C., Plan, D. and Rodriguez-Cerezo, E. (2012) Deployment of New Biotechnologies in Plant Breeding. Nature Biotechnology, 30, 231-239. https://doi.org/10.1038/nbt.2142

[57] Adikwu, M.U. (1998) Molecular Weight and Amylose/Amylopectin Ratio of the Starch from Gladiolus Actinomorphantus. Nigerian Journal of Natural Products and Medicine, 2, 54-56. https://doi.org/10.4314/njnpm.v2i1.11786

[58] Ahimbisibwe, M., Banadda, N., Seay, J., Nabuuma, B., Atwiju-kire, E., Wembabazi, E. and Nuwamanya, E. (2019) Influence of Weather and Purity of Plasticizer on Degradation of Cassava Starch Bioplastics in Natural Environmental Conditions. Journal of Agricultural Chemistry and Environment, 8, 237-250. https://doi.org/10.4236/jacen.2019.84018

[59] Xie, F., Yu, L., Chen, L. and Li, L. (2008) A New Study of Starch Gelatinization under Shear Stress Using Dynamic Mechanical Analysis. Carbohydrate Polymers, 72, 229-234. https://doi.org/10.1016/j.carbpol.2007.08.007

[60] Callari, J. (1998) Blown Film Strategies: With the Right Technology, You Can Go Where the Growth Is. Plastics Technology, February, 32.

[61] Butler, T. (1995) How to Extrude Plastomer Blown Film. Plastics Technology, February, 50 .

[62] Shogren, R. (1998) Starch: Properties and Materials Applications. In: Kaplan, D., Ed., Biopolymers from Renewable Resources, Springer, Berlin, New York, 30-46. https://doi.org/10.1007/978-3-662-03680-8 2

[63] Kalichevsky, M.T., Jaroszkiewicz, E.M., Ablett, S., Blanshard, J.M.V. and Lillford, P.J. (1992) The Glass-Transition of Amylopectin Measured by Dsc, Dmta and Nmr. Carbohydrate Polymers, 18, 77-88. https://doi.org/10.1016/0144-8617(92)90129-E

[64] Bilotti, E., Fischer, H.R. and Peijs, T. (2008) Polymer Nanocomposites Based on 
Needle-Like Sepiolite Clays: Effect of Functionalized Polymers on the Dispersion of Nanofiller, Crystallinity, and Mechanical Properties. Journal of Applied Polymer Science, 107, 1116-1123. https://doi.org/10.1002/app.25395

[65] Gidley, M.J. (1985) Quantification of the Structural Features of Starch Polysaccharides by NMR Spectroscopy. Carbohydrate Research, 139, 85-94. https://doi.org/10.1016/0008-6215(85)85074-6

[66] Bigio, D.I. (1997) Scale-Up in Polymer Processing. Extrusion Division RETEC, Asheville.

[67] Dean, K., Yu, L. and Wu, D.Y. (2007) Preparation and Characterization of MeltExtruded Thermoplastic Starch/Clay Nanocomposites. Composites Science and Technology, 67, 413-421. https://doi.org/10.1016/j.compscitech.2006.09.003

[68] Wang, J., Yu, L., Xie, F., Chen, L., Li, X. and Liu, H. (2010) Rheological Properties and Phase Transition of Cornstarches with Different Amylose/Amylopectin Ratios under Shear Stress. Starch-Starke, 62, 667-675. https://doi.org/10.1002/star.201000059

[69] Decaen, P., Rolland-Sabaté, A., Colomines, G., Guilois, S., Lourdin, D., Valle, G.D. and Leroy, E. (2020) Influence of Ionic Plasticizers on the Processing and Viscosity of Starch Melts. Carbohydrate Polymers, 230, 115591. https://doi.org/10.1016/j.carbpol.2019.115591

[70] Lourdin, D., Dellavalle, G. and Colonna, P. (1995) Influence of Amylose Content on Starch Films and Foams. Carbohydrate Polymers, 27, 261-270. https://doi.org/10.1016/0144-8617(95)00071-2

[71] Hoover, R. (2001) Composition, Molecular Structure, and Physicochemical Properties of Tuber and Root Starches: A Review. Carbohydrate Polymers, 45, 253-267. https://doi.org/10.1016/S0144-8617(00)00260-5

[72] Morrison, W.R., Tester, R.F., Snape, C.E., Law, R. and Gidley, M.J. (1993) Swelling and Gelatinisation of Cereal Starches. IV. Some Effects of Lipid-Complexed Amylose and Free Amylose in Waxy and Normal Barley Starches. Cereal Chemistry, 70, 385-391.

[73] Bocharnikova, I., Wasserman, L.A., Krivandin, A.V., Fornal, J., Blaszczak, W., Chernykh, V.Y., et al. (2003) Structure and Thermodynamic Melting Parameters of Wheat Starches with Different Amylose Content. Journal of Thermal Analysis and Calorimetry, 74, 681-695. https://doi.org/10.1023/B:JTAN.0000011001.02981.88

[74] Tan, I., Torley, P.J. and Halley, P.J. (2008) Combined Rheological and Optical Investigation of Maize, Barley and Wheat Starch Gelatinisation. Carbohydrate Polymers, 72, 272-286. https://doi.org/10.1016/j.carbpol.2007.08.018

[75] Cheetham, N.W.H. and Tao, L. (1998) Variation in Crystalline Type with Amylose Content in Maize Starch Granules: An X-Ray Powder Diffraction Study. Carbohydrate Polymers, 36, 277-284. https://doi.org/10.1016/S0144-8617(98)00007-1

[76] Rauwendaal, C. (2001) Polymer Extrusion. Carl Hanser, Munich. https://doi.org/10.1002/0471440264.pst126

[77] Tadmor, Z. and Klein, I. (1970) Engineering Principles of Plasticating Extrusion. Van Nostrand Reinhold, New York.

[78] Cantor, K. (1990) An Optimization Technique for the Extrusion of Blown Film Polyethylene. MS Thesis, Pennsylvania State University, State College.

[79] Chung, C.I. (2011) Extrusion of Polymers Theory and Practice. Hanser, Munich, 344-355.

[80] Sodergard, A., Selin, J.-F., Niemi, M., Johansson, C.-J. and Meinander, K. (2003) 
Processable Poly(hydroxy acids). US Patent 6,559,244B1.

[81] Hiltunen, E., Selin, J.-F. and Skog, M. (2000) Polyactide Films. US Patent 6,117,928.

[82] Schmack, G., Tandler, B., Vogel, R., Beyreuther, R., Jacobsen, S. and Fritz, H.G. (1999) Biodegradable Fibers of Poly(l-lactide) Produced by High-Speed Melt Spinning and Spin Drawing. Journal of Applied Polymer Science, 73, 2785-2797. https://doi.org/10.1002/(SICI)1097-4628(19990929)73:14<2785::AID-APP1>3.0.CO i2-L

[83] Randall, J.R., Ryan, C.M., Lunt, J., Hartman, M.H., Hall, E.S., Kolstad, J.J., et al. (2002) Impact Modified Melt-Stable Lactide Polymer Compositions and Processes for Manufacture Thereof. US Patent 6,495,631.

[84] Li, M., Liu, P., Zou, W., Yu, L., Xie, F., Pu, H., et al. (2011) Extrusion Processing and Characterization of Edible Starch Films with Different Amylose Contents. Journal of Food Engineering, 106, 95-101. https://doi.org/10.1016/j.jfoodeng.2011.04.021

[85] Walenta, E., Fink, H.-P., Weigel, P., Ganster, J. and Schaaf, E. (2001) Structure-Property Relationships of Extruded Starch, 2 Extrusion Products from Native Starch. Macromolecular Materials and Engineering, 286, 462-471.

https://doi.org/10.1002/1439-2054(200108)286:8<462::AID-MAME462>3.0.CO;2-A

[86] Ziegler-Borowska, M., Wegrzynowska-Drzymalska, K., Chelminiak-Dudkiewicz, D., Kowalonek, J. and Kaczmarek, H. (2018) Photochemical Reactions in Dialdehyde Starch. Molecules, 23, 3358. https://doi.org/10.3390/molecules23123358

[87] Graaf, R.A., De Karman, A.P. and Janssen, L.P.B.M. (2003) Material Properties and Glass Transition Temperatures of Different Thermoplastic Starches after Extrusion Processing. Starch, 55, 80-86. https://doi.org/10.1002/star.200390020

[88] Oniszczuk, T. and Janssen, L.P.B.M. (2009) Influence of Addition of Fiber on the Mechanical Properties of TPS Moldings. In: Janssen, L.P.B.M. and Moscicki, L., Eds., Thermoplastic Starch. A Green Material for Various Industries, Wiley-VCH, Weinheim, 197-208. https://doi.org/10.1002/9783527628216.ch11

[89] Wójtowicz, A. (2009) The Melting Process in Thermoplastic Starches. In: Janssen, L. and Moscicki, L., Eds., Thermoplastic Starch. A Green Material for Various Industries, Wiley, Weinheim, 105-117. https://doi.org/10.1002/9783527628216.ch5

[90] You, X., Li, L., Gao, J., Yu, J. and Zhao, Z. (2003) Biodegradable Extruded Starch Blends. Journal of Applied Polymer Science, 88, 627-635.

https://doi.org/10.1002/app.11533

[91] van den Einde, R., Bolsius, A., van Soest, J., Janssen, L., van der Goot, A. and Boom, R. (2004) The Effect of Thermomechanical Treatment on Starch Breakdown and the Consequences for Process Design. Carbohydrate Polymers, 55, 57-63. https://doi.org/10.1016/j.carbpol.2003.07.004

[92] Mościcki, L., Mitrus, M., Wójtowicz, A., Oniszczuk, T., Rejak, A. and Janssen, L. (2012) Application of Extrusion-Cooking for Processing of Thermoplastic Starch (TPS). Food Research International, 47, 291-299. https://doi.org/10.1016/j.foodres.2011.07.017

[93] Stasiak, M., Molenda, M., Opaliński, I. and Błaszczak, W. (2013) Mechanical Properties of Native Corn, Wheat and Potato Starches. Czech Journal of Food Sciences, 31, 347-354. https://doi.org/10.17221/348/2012-CJFS

[94] Zhang, J.-F. and Sun, X. (2007) Biodegradable Foams of Poly(lactic acid)/Starch. I. Extrusion Condition and Cellular Size Distribution. Journal of Applied Polymer Science, 106, 857-862. https://doi.org/10.1002/app.26715 
[95] Kuusipalo, J. (2001) Starch-Based Polymers in Extrusion Coating. Journal of Polymers and the Environment, 9, 125-135. https://doi.org/10.1023/A:1020402911494

[96] Koppolu, R., Lahti, J., Abitbol, T., Swerin, A., Kuusipalo, J. and Toivakka, M. (2019) Continuous Processing of Nanocellulose and Polylactic Acid into Multilayer Barrier Coatings. ACS Applied Materials \& Interfaces, 11, 11920-11927. https://doi.org/10.1021/acsami.9b00922

[97] Matzinos, P., Tserki, V., Kontoyiannis, A. and Panayiotou, C. (2002) Processing and Characterization of Starch/Polycaprolactone Products. Polymer Degradation and Stability, 77, 17-24. https://doi.org/10.1016/S0141-3910(02)00072-1

[98] Tajuddin, S., Xie, F., Nicholson, T.M., Liu, P. and Halley, P.J. (2011) Rheological Properties of Thermoplastic Starch Studied by Multipass Rheometer. Carbohydrate Polymers, 83, 914-919. https://doi.org/10.1016/j.carbpol.2010.08.073

[99] Della Valle, G., Boche, Y., Colonna, P. and Vergnes, B. (1995) The Extrusion Behaviour of Potato Starch. Carbohydrate Polymers, 28, 255-264. https://doi.org/10.1016/0144-8617(95)00111-5

[100] Follain, N., Joly, C., Dole, P., Roge, B. and Mathlouthi, M. (2006) Quaternary Starch Based Blends: Influence of a Fourth Component Addition to the Starch/Water/ Glycerol System. Carbohydrate Polymers, 63, 400-407. https://doi.org/10.1016/j.carbpol.2005.09.008

[101] Maddams, W. and Preedy, J. (1978) X-Ray Diffraction Orientation Studies on Blown Polyethylene Films. I. Preliminary Measurements. Journal of Applied Polymer Science, 22, 2721-2737. https://doi.org/10.1002/app.1978.070221001

[102] Kwack, T., Han, C. and Vickers, M. (1988) Development of Crystalline Structure during Tubular Film Blowing of Low-Density Polyethylene. Journal of Applied Polymer Science, 35, 363-389. https://doi.org/10.1002/app.1988.070350207

[103] Fahrngruber, B., Siakkou, E., Wimmer, R., Kozich, M. and Mundigler, N. (2017) Malic Acid: A Novel Processing Aid for Thermoplastic Starch/Poly(butylene adipate-co-terephthalate) Compounding and Blown Film Extrusion. Journal of Applied Polymer Science, 134, 45539. https://doi.org/10.1002/app.45539

[104] Giles, H.F., et al. (2014) Extrusion: The Definitive Processing Guide and Handbook. Second Edition, Crescent Associates Inc., Rochester, 540-541.

[105] Brampton Engineering Inc., 8031 Dixie Road, Brampton, Ontario.

[106] Reifenhauser Incorporated, 2 Washington Street, Ipswich, MA.

[107] American Kuhne Inc., 31 Connecticut Avenue, Norwich, CT 06360.

[108] Black Clawson Converting Machinery LLC, 46 North First Street, Fulton, NY.

[109] Feiertag, B.A. (1999) Air Entrainment in Plastic Film Handling and Windingdthe State of the Art. ANTEC Conference Proceeding, New York, 283.

[110] A. R. Engineering Machine Inc., 1061 Brevik Place, Mississaugua, Ontario.

[111] NDC Infrared Engineering, 5314 North Irwindale Ave., Irwindale, CA.

[112] Gupta, A., Simpson, D. and Harrison, I. (1993) A Morphological Study of HDPEBlown Films Using Small-Angle X-Ray Scattering. Journal of Applied Polymer Science, 50, 2085-2093. https://doi.org/10.1002/app.1993.070501206

[113] (2008) Piggy-Back Extruders for 11-Layer Blown Film. Plastics Technology, June, 19.

[114] Plast-Control Inc., 29 Green Street, Newburyport, MA.

[115] Anonymous (1996) What You Need to Know about Running Metallocene LLDPEs. Plastics World, July, 41. 
[116] Dowd, L.E. (1986) Blown Film Extrusion. United States Patent 4632801.

[117] Todd, H.R., Allen, K.D. and Alting, L. (1994) Manufacturing Processes Reference Guide. Industrial Press Inc., 131-132.

[118] Thurnwall, M., Kutanova, V., Boldizar, A. and Rigdahl, M. (2008) Film Blowing of Thermoplastic Starch. Carbohydrate Polymers, 71, 583-590. https://doi.org/10.1016/j.carbpol.2007.07.001

[119] Thuwall, M., Boldizar, A. and Rigdahl, M. (2006) Extrusion Processing of High Amylose Potato Starch Materials. Carbohydrate Polymers, 65, 441-446. https://doi.org/10.1016/j.carbpol.2006.01.033

[120] Addex Inc., 295 Lincoln Street, Hingham, MA.

[121] Chinsirikul, W., Kerddonfag, N., Winotapun, C. and Khumsang, P. (2008) Plastic Extrusion Asia. Tech. Paper, 55.

[122] Wu, C.Y., Lui, W.B. and Peng, J. (2018) Optimization of Extrusion Variables and Maleic Anhydride Content on Biopolymer Blends Based on Poly(hydroxybutyrateco-hydroxyvalerate)/Poly(vinyl acetate) with Tapioca Starch. Polymers, 10, 827. https://doi.org/10.3390/polym10080827

[123] Nasr, M., Tawfik, A., Suzuki, M. and Ookawara, S. (2014) Mathematical Modeling of Bio-Hydrogen Production from Starch Wastewater via Up-Flow Anaerobic Staged Reactor. Desalination and Water Treatment, 54, 50-58.

https://doi.org/10.15376/biores.8.4.4951-4968

[124] Rakos, R. and Sebastian, D. (1990) Design and Optimization of Extrusion Dies Using Computer Based Simulations. Advances in Polymer Technology, 10, 297-307. https://doi.org/10.1002/adv.1990.060100406

[125] Chabrat, E., Rouilly, A., Evon, P., Longieras, A. and Rigal, L. (2010) Relevance of Lab-Scale Conical Twin-Screw Extruder for Thermoplastic STARCH/PLA Blends Rheology Study. PPS-26 Polymer Processing Society 24th Annual Meeting, 4-8 July 2010.

[126] Martin, O., Averous, L. and Della Valle, G. (2003) In-Line Determination of Plasticized Wheat Starch Viscoelastic Behavior: Impact of Processing. Carbohydrate Polymers, 53, 169-182. https://doi.org/10.1016/S0144-8617(03)00040-7

[127] Rudnik, E. (2008) Compostable Polymer Materials. Elsevier Publishing, Amsterdam, 28-31, 183-198.

[128] Madival, S., Auras, R., Singh, S. and Narayan, R. (2009) Assessment of the Environmental Profile of PLA, PET and PS Clamshell Containers Using LCA Methodology. Journal of Cleaner Production, 17, 1183-1194.

https://doi.org/10.1016/j.jclepro.2009.03.015

[129] Vink, E., Davies, S. and Kolstad, J. (2010) The Eco-Profile for Current Ingeo ${ }^{\circledR}$ Polylactide Production. Industrial Biotechnology, 6, 212-225. https://doi.org/10.1089/ind.2010.6.212

[130] Greene, J.P. (2014) Sustainable Plastics: Environmental Assessments of Biobased, Biodegradable, and Recycled Plastics. John Wiley \& Sons, Inc., Hoboken.

[131] Zanela, J., Casagrande, M., Reis, M.O., Grossmann, M.V.E. and Yamashita, F. (2017) Biodegradable Sheets of Starch/Polyvinyl Alcohol (PVA): Effects of PVA Molecular Weight and Hydrolysis Degree. Waste and Biomass Valorization, 10, 319-326. https://doi.org/10.1007/s12649-017-0051-6

[132] Zanela, J., Bilck, A.P., Casagrande, M., Grossmann, M.V.E. and Yamashita, F. (2018) Oat Fiber as Reinforcement for Starch/Polyvinyl Alcohol Materials Produced by Injection Molding. Starch-Stärke, 70, Article ID: 1700248. 
https://doi.org/10.1002/star.201700248

[133] Cantor, K. (2019) Blown Film Extrusion. Hanser, Munich. https://doi.org/10.3139/9781569906972.fm

[134] Ahammad, M. and Minh Nguyen, T. (2016) Influence of the Presence of Chemical Additives on the Thermal Properties of Starch. Food and Nutrition Sciences, 7, 782796. https://doi.org/10.4236/fns.2016.79079

[135] Shah, A.A., Hasan, F., Hameed, A. and Ahmed, S. (2008) Biological Degradation of Plastics: A Comprehensive Review. Biotechnology Advances, 26, 246-265. https://doi.org/10.1016/j.biotechadv.2007.12.005

[136] Emadian, S.M., Onay, T.T. and Demirel, B. (2017) Biodegradation of Bioplastics in Natural Environments. Waste Management, 59, 526-536. https://doi.org/10.1016/j.wasman.2016.10.006

[137] Rudnik, E. and Briassoulis, D. (2011) Degradation Behaviour of Poly(lactic acid) Films and Fibres in Soil under Mediterranean Field Conditions and Laboratory Simulations Testing. Industrial Crops and Products, 33, 648-658. https://doi.org/10.1016/j.indcrop.2010.12.031

[138] Williams, E. and Williams, P. (1997) Analysis of Products Derived from Fast Pyrolysis of Plastic Waste. Journal of Analytical and Applied Pyrolysis, 40-41, 347-363. https://doi.org/10.1016/S0165-2370(97)00048-X

[139] Kurokawa, H., Ohshima, M., Sugiyama, K. and Miura, H. (2003) Methanolysis of Polyethylene Terephthalate (PET) in the Presence of Aluminium Triisopropoxide Catalyst to Form Dimethyl Terephthalate and Ethylene Glycol. Polymer Degradation and Stability, 79, 529-533. https://doi.org/10.1016/S0141-3910(02)00370-1

[140] Basurko, O. and Mesbahi, E. (2014) Methodology for the Sustainability Assessment of Marine Technologies. Journal of Cleaner Production, 68, 155-164. https://doi.org/10.1016/j.jclepro.2012.01.022

[141] Narayan, R. (2011) Rationale, Drivers, Standards, and Technology for Biobased Materials. In: Graziani, M. and Fornasiero, P., Eds., Renewable Resources and Renewable Energy: A Global Challenge, 2nd Edition, CRC Press, Boca Raton, 10-16.

[142] Chen, F., Zhang, M. and Wu, Z. (2010) Toward Delivery of Multiple Growth Factors in Tissue Engineering. Biomaterials, 31, 6279-6308.

https://doi.org/10.1016/j.biomaterials.2010.04.053

[143] Lasprilla, A., Martinez, G., Lunelli, B., Jardini, A. and Filho, R. (2012) Poly-Lactic Acid Synthesis for Application in Biomedical Devoces-A Review. Biotechnology Advances, 30, 321-328. https://doi.org/10.1016/j.biotechadv.2011.06.019

[144] Dearnaley, G. and Arps, J. (2005) Biomedical Applications of Diamond-Like Carbon (DLC) Coatins: A Review. Surface \& Coatings Technology, 200, 2518-2524. https://doi.org/10.1016/j.surfcoat.2005.07.077 